DOI https://doi.org/10.30525/978-9934-26-183-1-24

\title{
APPLICATION OF INTEGRATED METHODS FOR ESTIMATION OF ENGINEERING-GEOLOGICAL CONDITIONS OF MAN-MADE TERRITORIES
}

\author{
Koshliakov O. Ye. \\ Doctor of Geological Sciences, \\ Head of the Department of Hydrogeology and Engineering Geology, \\ Institute of Geology \\ Taras Shevchenko National University of Kyiv \\ Dyniak O. V. \\ Candidate of Geological Sciences, \\ Associate Professor at the Department \\ of Hydrogeology and Engineering Geology, \\ Institute of Geology \\ Taras Shevchenko National University of Kyiv \\ Koshliakova I. Ye. \\ Engineer at the Department of Hydrogeology and Engineering Geology \\ Institute of Geology \\ Taras Shevchenko National University of Kyiv, \\ Kyiv, Ukraine
}

Today, almost $80 \%$ of the territory of Ukraine is in a man-made state. Urbanization of the country, the creation of powerful mining, hydraulic, reclamation, agro-industrial and other technological complexes, nuclear and thermal power plants have led to a significant increase in man-made loads on the upper geological environment and intensification of exogenous geological processes in the regional plan. The complex problem of changes in engineering and geological conditions of territories under the influence of man-made factors is gaining regional development and requires the development of scientific bases and scientifically sound comprehensive assessments of these changes and their implementation.

To determine the engineering-geological conditions (EGC) of the territories and further monitoring of their condition, it is expedient to carry out engineering-geological typing and engineering-geological zoning. The purpose of engineering-geological typing of a certain area is to identify the main regional factors of the geological environment and patterns of 
development of engineering-geological processes, which to some extent affect the state of objects located in these areas.

As you know, EGC is determined mainly by geostructural and geomorphological conditions, which in turn vary significantly depending on the position of the territory in a particular geostructural area, geographical area. Data are obtained on the basis of engineering and geological monitoring and using stock and archival materials [2, p. 6].

The EGC assessment is based on the principles of combining geological, historical and environmental approaches, and has the following distinctive features: relativity, special character and specificity. Relativity is due to incomplete knowledge of the studied volume of the geological environment, its structure, the processes that guide its development. The special nature and specificity stem from the fact that evaluations are always carried out with a fixed purpose. Assessment of engineering and geological conditions can be presented in quantitative and qualitative form. As the assessment is detailed, the role of quantitative assessments of indicators increases [1, p. 96].

The use of integrated methods to assess EGC allows to identify, map and predict patterns and dynamics of negative changes in the geological environment and its main parameters (geochemical, hydrogeological, engineering-geological), which directly or indirectly affect the ecological state of territories, regions, state as a whole. One of the main issues is the development of a system of evaluation criteria and indicators, both as a whole and its individual components. Without an agreed system of such criteria, it is impossible to perform a reasonable mapping of parameters and characteristics of the geological environment that can be used for ecological and geological conclusions $[4$, p. 42].

In modern methodological developments, proposals for the formation of criteria for only certain components of the geological environment are often presented. Integral indicators are often far from clear and unambiguous.

When collecting the necessary materials and data, the authors believe that the accumulated and systematized information should highlight the role and importance of natural and man-made (anthropogenic) factors in shaping the ecological state of the geological environment. Accordingly, data on the state of the geological environment and the factors that determine it, it is advisable to divide into two groups: natural and man-made. Depending on the economic conditions and priorities that are addressed in specific areas, methodological approaches to the assessment of EGC can vary widely.

As the EGC 's integrated assessment for different types of engineering development is detailed, the role of quantitative indicators increases significantly. In determining the role of selected calculation complexes in the formation of the IHU of a particular area and their impact on engineering 
activities, their ordering is carried out with the determination of the quantitative value of the weighting factor.

To identify the main factors in the formation of EGC and determine the list of settlement complexes, it is necessary to use basic maps that have a common and legitimate content, as well as a way to display the information that is needed. In order to take into account the properties of the components of the geological environment and their degradation under the influence of engineering activities, to determine the category of favorable EGC for engineering development, maps are grouped as follows: soil suitability geological and engineering-geological; geomorphological conditions geomorphological and manifestation of geological processes; influence of groundwater - hydrogeological and manifestation of geological processes [3, p.1-5]. The need for grouping maps is due to the procedure of checking the significance of the selected calculation complexes on the main one, which is the basic one. The main requirement for maps is uniformity and reflection on them of indicators, on the basis of which it is possible to make a reasonable selection of areas homogeneous in structure and with a close response to engineering development. To take into account the spatial variability of the IHU, all maps were divided into an equal number of equal squares operational-territorial units. Each of them is assigned an operating index.

Given that each point of the geological environment has a set of indicators that characterize its properties, and operations with a multidimensional field of indicators are very time consuming, the introduction of an integrated indicator allows to deal with a field of one value that characterizes the whole set of properties. Of course, the integrated indicator should represent as much as possible the variety of states of the components and contain the maximum information about them.

If the area for which EGC is are assessed is quasi-homogeneous in terms of components, then we have one value of the integrated indicator. In the case of heterogeneity of the territory, the integrated indicator is calculated for each quasi-homogeneous area and the model of the field of integrated indicators is rebuilt, which allows to estimate the category of EGC complexity in any part of the simulated area.

To move to scalar values in the calculation of the integrated indicator should use the method of scoring expert assessments. Due to the different level of scientific and methodological development of the selected calculation complexes in the regulatory documentation, each of them can be divided into a certain number of conditional points.

The introduction of normalized scores and coefficients of significance reduces the subjectivity inherent in the expert method of solving multicriteria problems. An integral indicator of IHU is the weighted average score, which 
is defined as the sum of the normalized scores of calculation complexes, taking into account the prevalence of the latter in the territory [4, p. 46].

At the next stage it is necessary to build risk maps of exogenous geological processes specific to the study area. Using GIS technologies, the plane parameter of propagation of the impact of a dangerous process obtained earlier is assigned a score of the intensity of the impact of each type of engineering and geological processes separately. The result of this stage will be a set of risk maps of manifestations of engineering and geological processes for each of their types separately.

Next, it is advisable to perform a spatial combination of the obtained maps. The purpose of summarizing the data is to determine the integrated risk of exogenous geological processes characteristic of the study area. It is advisable to summarize these risk maps using GIS technology tools. Using automated algorithms of summation and spatial integration, allows you to sum up not only the planar parameter, but also scores for each of the types of engineering and geological processes.

In complex systems of not only engineering-geological, but also hydrogeological, geological and ecological monitoring and management, an important functional task is to create a single information space in which information obtained from different sources is integrated on a spatial basis.

\section{References:}

1. Диняк O.B., Кошлякова I.C. Dinyak O., Koshlyakova I. Використання геоінформаційних баз даних для оптимізації інженерно-геологічних досліджень на урбанізованих територіях // Вісник Одеського національного університету. Серія: Географічні та геологічні науки. Том 18. - 2013. -№1(17). - С. 96-101.

2. Грохольский Н. С. Методика определения интегрального риска экзогенных геологических процессов // Геориск. - 2013. - № 2. C. 46-47.

3. Koshliakov O., Dyniak O., Koshliakova I. Tehnogenic infiltration nutrition component underground water as a factor the emergence and activation of dangerous exogenous processes in industrial and city agglomerating territories. Abstracts of XI International Scientific Conference «Monitoring of Geological Processes and Ecological Condition of Environment» 2017, Kyiv, Ukraine. P. 1-5.

4. Prusov D.E. The Methodology for the Forecasting Consequences of Engineering Preparation for Transformation the Urban Areas in Dense Building and Complex Geology conditions // Proceedings of the National Aviation University. - 2015. - Vol. 63, No. 2. P. 40-45. 